Journal of

Entreprenuership and

Project Management

(JEPM)

FACTORS CONTRIBUTING TO DECLINATION OF WOMEN PROJECTS FUNDED BY LOCAL MFIS

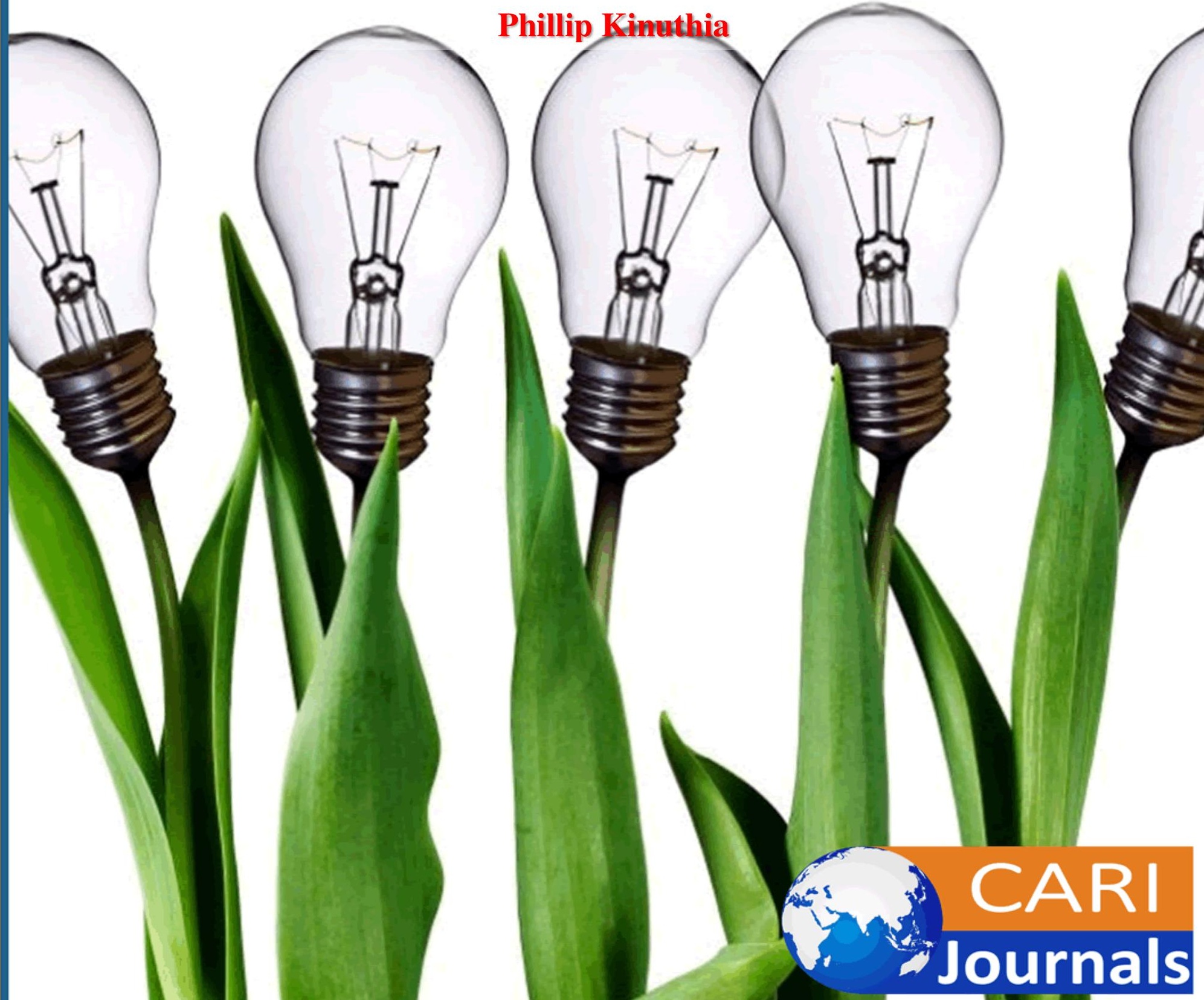




\title{
FACTORS CONTRIBUTING TO DECLINATION OF WOMEN PROJECTS FUNDED BY LOCAL MFIS
}

\author{
1* Phillip Kinuthia \\ $1^{*}$ Undergraduate student, Catholic University of Eastern Africa \\ *Corresponding Author's Email: pkwahinya@yahoo.co.uk
}

\begin{abstract}
Purpose: The purpose of this study was to examine the factors contributing to declination of women projects funded by local MFIs

Methodology: A qualitative and quantitative case study was adopted. The target population was included all the Kabete women groups financed by the KWFT Kabete branch. The number of groups was 200 with a total of 1000 members. As it not feasible for the researcher to study every member in the target population, a sample of $10 \%$ was considered representative. A nonrandom sampling technique was used to select 3 respondents from the various groups where the group leaders such as chair lady, treasurer and secretary were requested to fill in the questionnaires which were the instruments for data collection. The data collected was analyzed by use of descriptive and inferential statistics.

Results: Findings indicated that the main causes of failure of women projects funded by MFIs can be attributed to the general SME constraints such as competition, lack of technical training and capacity building and inappropriate information and technology. In addition, genders issues such as women immobility, lack of confidence, inadequate time and unequal distribution of productive resources contributed to failure. It was also found that low degree of formal training in various business areas was a state common with many women undertaking projects funded by local MFIs. It was found that despite local MFIs offering flexible borrowing and repayment terms, majority of women borrowers found it difficult to repay loans on time. It was also found that majority of women projects had not expanded nor contracted, that is, they had no noticeable growth. Nonetheless, it was unfortunate that a significant portion of women projects had actually collapsed as a result of the general and gender constraints listed in this study.
\end{abstract}

Unique contribution to theory, practice and policy: It was recommended that general constraints to SMEs and gender disparities needed to be sorted out. The policy calling for improvement in the legal and regulatory framework require a comprehensive review of all pertinent Acts in order to determine the extent to which such acts have adverse impact on SMEs. The government effort to create markets such as Muthurwa and the other potential markets should be reinforced by the provision of amenities such as water, sanitation and electricity in those markets. Furthermore, more work places and land need to be set aside for the construction of effective trading structures. The government and stakeholders as well need to come together and establish public private partnerships with the mandate of providing business training as well building capacity among SME owners. The researcher recommends a study on an analytical 
Journal of Entrepreneurship and Project Management

ISSN 2520 - 9116 (Online)

Vol.2, Issue No.2, pp 17- 39, 2017

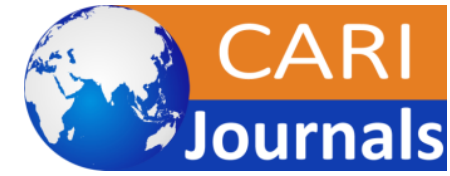

www.carijournals.org

study shedding light to the reasons for the slow implementation of various policies aimed at benefiting the SME sector

Keywords: women projects, declination, micro-credit, capacity building, cash flow management, MFIs

\subsection{INTRODUCTION}

Micro credit is the extension of very small loans (micro loans) to the unemployed, to poor entrepreneurs and to others living in poverty, who are not considered bankable. These individuals lack collateral, steady employment and a verifiable credit history and therefore cannot meet even the most minimal qualifications to gain access to traditional credit. Micro credit is a part of microfinance, which is the provision of a wider range of financial services to the very poor. (www.wikipedia.org)

According to Bheemaraya (2016), micro credit is a financial innovation which originated in Bangladesh where it has successfully enabled extremely impoverished people to engage in selfemployment projects that allow them to generate an income. In addition, it has enabled the poor to build wealth and exit poverty. Due to the success of micro credit, many in the traditional banking industry have begun to realize that these micro credit borrowers should more correctly be categorized as pre-bankable; thus, micro credit is increasingly gaining credibility in the mainstream finance industry and many traditional large finance organizations are contemplating micro credit projects as a source of future growth. Although almost everyone in larger development organizations discounted the likelihood of success of micro credit when it was begun in its modern incarnation as pilot projects with ACCION and Muhammad Yunus in the mid-1970s, the United Nations declared 2005 the International Year of Micro credit.

Women have become the focus of many micro credit institutions and agencies worldwide. The reasoning behind this is the observation that loans to women tend to more often benefit the whole family than loans to men do. It has also been observed that giving women the control and the responsibility of small loans raises their socio-economic status, which is seen as a positive change to many of the current relationships of gender and class (D'espallier, Guérin, \& Mersland, 2011). The Kenya Women Finance Trust (KWFT), an affiliate of Women's World Banking, has been working towards strengthening women's participation in the economic mainstream. Focused on women who have little access to formal credit, it provides requisite training to help women entrepreneurs. KWFT started its operations in early 1980s with several donors providing grants. After a restructuring in 1990s KWFT focused on a group based credit strategy that improved its performance immensely. KWFT has since emerged as a reliable source of quick credit to rural women, promoting entrepreneurship and empowerment by providing additional sources of income. It has also created long- lasting bonds among the members, which has contributed to social harmony.

\subsection{Statement of the Problem}

A review of the literature indicates that micro-credit and its role in empowering women is a topic that has received its fair share of attention from scholars, economists as well as policy makers. Mayoux (2000), in her study 'Micro-finance and the empowerment of women: a review of the 
key issues', highlighted the fundamentals of financing women projects and the challenges faced by women in Africa. Another study by Kabeer (1998) entitled "'Money can't buy me love": reevaluating gender, credit and empowerment in rural Bangladesh", highlighted the gender disparity as a hitch in women economic empowerment.

Nonetheless, it has been noted that despite various recommendations from these studies, women in Africa and particularly in Kenya are still faced by challenges that ought to have been solved by empowerment through micro credit. It has been noted that most projects financed through micro credit end up being liabilities to the women borrowers themselves. This could partly be the characteristic nature of micro and small enterprises as most do not survive the harsh economic, legal, cultural and global environment. Nonetheless, it is most important that these SMES survive and grow as they are recognized to be the panacea to unemployment and abject poverty.

A narrower focus at Kabete women projects funded by KWFT echoes the same sentiments. Despite KWFT managing a collection rate of above $98 \%$, the hustle undergone by the women borrowers to make this collection rate possible is beyond respite. Most of the women borrowers have to be bailed either by fellow group members or by friends and family members. This status quo begs the question: "What happened to the projects which were supposed to generate cash flow over and above the repayment amount?" This question can only be answered by an empirical analysis of the same projects to determine their failure and allow the generation of possible solutions to the impediments facing this projects. It is with this thought in mind that the researcher undertakes this study. In addition, the researcher will be covering an evident research gap as the Kabete district has not received scholastic and research attention.

\subsection{Research Objectives}

i. To analyze the general and unique problems facing women's projects/SMEs such as lack of institutional capacity.

ii. To investigate the training needs of women/capacity building

iii. To determine the underlying problem that plague cash flow management from the beneficiary's point of view.

iv. To investigate whether micro credit has improved the general welfare of the beneficiaries.

v. To suggest local solutions as well as solutions that have worked in other countries such as Bangladesh

\subsection{LITERATURE REVIEW}

\subsection{SME Definitions}

The definitions used to describe the MSE sector in Kenya are based on employment size (and include both paid and unpaid workers). A micro-enterprise is defined as having no more than 10 employees; a small enterprise with 11-50 employees; and a medium/large enterprise with more than 50 employees. Farm holdings are excluded from the definition of MSEs, except those farmbased enterprises that involve some sort of processing before marketing. For example, a farmer who goes to market to sell roasted maize at the marketplace or at the roadside is seen as operating an MSE. Thus, the term micro and small enterprise covers the range of establishments, 
Journal of Entrepreneurship and Project Management

ISSN 2520 - 9116 (Online)

Vol.2, Issue No.2, pp 17- 39, 2017

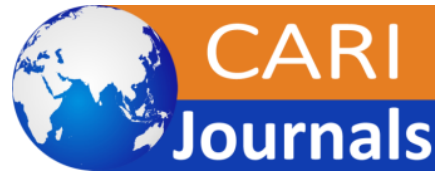

Www.carijournals.org

including informal economy activities that include one or more persons and enterprises in the formal economy employing up to 50 persons. The Ministry of Labour and Human Resource Development (MLHRD), which is the lead government agency for the MSE sector, makes provision for both formal and informal enterprises, classified into on-farm and non-farm categories, employing 1-50 employees (Stevenson et al, 2005).

In GOK paper No.2 of 1986 and 1997, the government recognizes the importance of small enterprise sector as a primary means of strengthening Kenyan's economy through industrialization and enhancing private sector contribution to national economic growth. Small enterprise sector includes a variety of economic activities that responds to a wide range of market demand and opportunities. Economic activities are either in service and trade industry. The size of the sector has commonly been determined by the number of employees. In the Kenyan context the sector employs between 0-50 people per enterprise (GOK, 1992). The sector has two clusters as follows: (McCormick, 1992)

- $\quad$ Micro enterprises - these are the smallest and employ between 0-10 people,

- $\quad$ Small enterprises employ 11 to 50 workers.

\subsection{Gender and the Performance of Women's Enterprises}

McCormick (2001) noted significant differences in the performance of women's enterprises visà-vis those of Kenyan men. Their enterprises are smaller, less likely to grow, less profitable, and begin with less capital investment than those owned by men. Not only is there a great deal of gender segregation by sector (with women dominating in food processing, beer brewing, hairdressing, dressmaking, and retail of second-hand clothing, while men dominate in metalwork, carpentry, vehicle repair, shoe making, construction and transport), but women and men operate from different locations. Men are twice as likely as women to locate in trading centers, commercial districts or roadside locations; women are almost twice as likely to be operating from the home. Women are three times as likely as men to belong to some type of business association, although there are indications that women's networks have less power to assist their businesses (Stevenson et al., 2005)

McCormick (2001) isolated three factors that account for these differences in enterprise performance. The first factor has to do with the level of education. On average, women entrepreneurs are less educated than their male counterparts and twice as likely as men to be illiterate. The major reasons for this difference are institutional in nature. Marriage institutions discourage investment in women's education and the division of labor assigns a greater share of household responsibility to girls. Because they have lower educational attainment, they are also less likely to benefit from management and technical training programs. The second factor has to do with the opportunity to accumulate savings. Because women have lower levels of education and are segregated into lower paying jobs, they have lower savings with which to start a business. Thirdly, women spend less time in their businesses than men because they are expected to carry out their domestic responsibilities, including housework, food preparation and childcare. This also explains why women are more likely to operate their business from the home. McCormick concludes that gendered patterns of business operations are supported by five institutions - the incorporation of the wife into the husband's family, the division of labor within 
Journal of Entrepreneurship and Project Management

ISSN 2520 - 9116 (Online)

Vol.2, Issue No.2, pp 17- 39, 2017

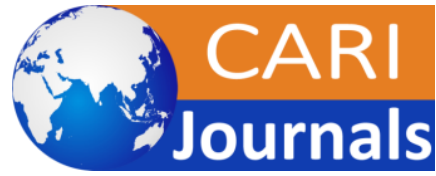

www.carijournals.org

the household, the division of asset ownership (the tradition that vests ownership of land in males remains strong, even though women can purchase and inherit land), the sharing of household expenditures, and the allocation of educational opportunities.

As the data confirms, the larger the group of enterprises, the fewer women entrepreneurs one will find. Over 85 per cent of the enterprises owned by women do not have any employees except the owner. Of the 9,041 small enterprises (1999) with 11-50 employees, it is estimated that women own fewer than 20 per cent; this amounts to less than 0.3 per cent of all women-owned MSEs! (Stevenson \& St-Onge, 2005).

\subsection{The Profile of the Kenyan Woman Entrepreneur}

Although there is limited available research on the profile of Kenyan women entrepreneurs, there is certainly anecdotal evidence that this profile is not homogeneous, perhaps falling into three segments. Women in each segment differ slightly from those in the others in terms of their demographic profile, extent of previous business experience, capacity, needs, access to resources (credit, premises, and BDS), and orientation towards growth (Stevenson \& St-Onge, 2005). The first segment is that of the Jua Kali micro-enterpriser The women who own these enterprises, often unregistered and in the informal economy, have little education (less than secondary level), and are constrained by their lack of entrepreneurial and business know-how, access to credit, and awareness of markets and market opportunities. Key informants indicated that they might be further constrained by their household responsibilities and the need to obtain permission from their husbands to travel out of town for training or trade fairs. Husbands were also reported to object if their wives participated in training and counseling services provided by men. Since men make up about 90 per cent of the trainers and business service providers in Kenya, this is particularly problematic. These women start very small enterprises, most likely only employ themselves or a few family members, and operate from a home base or Jua Kali shed (Stevenson $\&$ St-Onge, 2005). Their enterprises have limited potential for growth. To obtain credit for her business, a woman is likely to participate in a "merry-go-round" group of five or six women who combine their savings over a six-month period of time and then start lending, on a very shortterm basis, to members from the pool. One woman entrepreneur (a key informant during the mission's consultations) referred to this group as the grassroots "underclass". Several key informants stressed that many Jua Kali women have the potential to move into the "economic grid", but need more support, encouragement, visibility and economic empowerment (Stevenson \& St-Onge, 2005).

The second segment is comprised of women with very small (6-10 employees) and small enterprises (over 10 employees) who have a minimum of secondary education, previous experience as an employee in a public or private sector enterprise, and a supportive husband who may be directly or indirectly involved in the business. Their businesses are generally registered and operate from legitimate business premises. Although these women are more likely to be able to access business development services (BDS), training and micro-finance, they are still constrained by access to financing. Once they have surpassed the lending limits of micro-finance organizations (over Kshs. 500,000), they are still likely below the threshold to be of interest to commercial banks, which prefer to lend to large depositors. Furthermore, they are unlikely to 
have title deeds and cannot meet collateral security requirements. Many of the firms owned by these women have growth potential; some already tapping into international markets.

The third segment is made up of women with university education, who came from entrepreneurial family backgrounds, have experience in managerial positions in the corporate world, access to financial means and supportive husbands. This group was referred to in key informant interviews as the "elitist class". These women are amongst the group most likely to have small, medium-sized or larger enterprises with growth potential and the group most likely to be engaged in exporting. Each of these three groups of women entrepreneurs are in need of tailored responses to their specific enterprise needs (see Figure 1). However, the groups most in need of targeting may be at the "top end" of the bottom segment and the middle segment - the groups referred to as the "missing middle" of women entrepreneurs. Kenyan women entrepreneurs at the micro, Jua Kali level, have great difficulties obtaining financing due to collateral constraints. Most of them are forced to cooperate with other women in small groups to mobilize savings and pool these resources for lending to individual group members. Alternatively, they form in small groups to access micro-credit, through a mutual guarantee system, from a micro-finance organization, such as the Kenya Women Finance Trust (KWFT) or the Women Economic Empowerment Consort (WEEC).

According to key informants, men have an easier time accessing credit because they are more likely than women to have title deeds to offer as loan collateral. This enables them to function on an "individual" basis more so than women, who must use the group to pool resources. As expressed by one key informant, "men standalone better than women ... women still need to work in groups". Women who make it beyond the micro-enterprise threshold of more than five employees are seen as more able to stand on their own, but they often lack sufficient working capital to prepare for a growth in demand, unable to fulfill a large order because they do not have the working capital to finance raw materials and work-in-progress inventory. The interest rates of commercial banks range from 16 to 21 per cent, and they prefer to cater to clients who have large deposits. For these reasons, several key informants stated that a scheme is needed to provide credit to those women who are trying to pursue growth objectives - lower interest loans to meet their capital investment and working capital needs (Stevenson \& St-Onge, 2005).

Women with larger enterprises are more sophisticated, better educated; more experienced, more traveled, and have access to more networks, information and resources. However, they would benefit from better access to information regarding market opportunities, export procedures, and leadership development. Although this group may have greater access to collateral, they may still face some barriers to obtaining flexible financing for the further development of their enterprises. Gakure (1995) found that women with growth-oriented enterprises often have very influential husbands in the civil service or in the private sector.

\subsubsection{The Three Segments of Women Entrepreneurs: Gaps and Needs}

For growth, all women entrepreneurs would benefit greatly from a supportive environment that encourages women to "go for it". Currently, there is a lack of social and cultural support for the role of women as entrepreneurs; women are subject to stereotypes and there are few visible role models for them at any level. Gender barriers need to be addressed at all levels, from the legal system to the domestic system. Women entrepreneurs also need more access to a full range of 
financial and non-financial support services. The growth of their enterprises is restricted by a lack of collateral and flexible finance options. There is inadequate access to training, as well as follow-up to training inputs, and limited opportunity to avail them of external, formal managerial capacity-building support. In addition, they have difficulties finding land and premises for production/services and acquiring up-to-date technology. Finally, they would benefit from the strength of numbers that would be gained through representation by a women entrepreneurs' association, which would not only provide networking and value-added membership services, but also a collective "voice" for the needs and concerns of women entrepreneurs in the country(Stevenson \& St-Onge, 2005)..

\subsection{Micro-Credit and Equality between Women and Men}

What is the relationship between women's empowerment and micro-credit programs?

Micro-credit, micro-finance and micro-enterprise are now seen as effective poverty alleviation mechanisms, especially for poor women. The 1997 Micro-Credit Summit Campaign aims to ensure that "100 million of the world's poorest families, especially the women of those families, receive credit for self-employment and other financial and business services by the year 2005." Many micro-credit schemes specifically target women as they have proven to be very good credit risks with high repayment ratios even with credit at market rates. www.sida.se

Proponents argue that as well as increasing women's income, there are other benefits:

a. Improvements in women's role in the household (i.e. through the provision of economic resources, a woman may gain a greater voice in expenditure decisions)

b. Increased confidence for women gained not only through the economic success of their business but also through increased access to community services and collective action with other women.

c. Changes at the community level in the perceptions of women's roles.

Yet there is now evidence that questions an automatic relationship between participation in a micro-credit (or micro-enterprise) scheme and empowerment. Specific issues include:

- Concerns have been raised that given women's unequal position within the family, women's loans may be ultimately controlled by male family members.

- Despite increases in income, many participants report an increased overall workload, as there is no respite from their domestic responsibilities.

- Many aspects of gender inequality cannot be dealt with through micro-credit. These include discriminatory labor practices, violence, unequal division of domestic responsibilities, and educational biases.

- $\quad$ Self-employment may not be women's (or men's) first choice. A job in the formal sector (with more security, benefits and protection) may be the preferred option.

The argument is not to abandon micro-credit programs, but rather give careful consideration to what these programs can actually achieve - both generally and in relation to women's empowerment. . www.sida.se. How is equality between women and men relevant to microcredit? Reviews of experiences demonstrate that poor women face specific obstacles to both 
Journal of Entrepreneurship and Project Management

ISSN 2520 - 9116 (Online)

Vol.2, Issue No.2, pp 17- 39, 2017

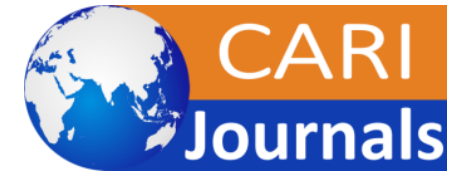

Www.carijournals.org

participating in and benefiting from micro-credit and micro-enterprise programs. In order to ensure more equitable results, special attention should be paid to:

$\S$ Unequal access to productive resources: Given inequalities within the household, lack of formal property titles and fewer employment opportunities, women may have more difficulty than men providing collateral for loans and generating capital.

$\S$ Education levels: Poor women generally have less education than poor men. They often find it difficult to fill in forms or participate in training that requires a specific literacy level or vocational skills.

$\S$ Confidence: Women often have less self- confidence. They may be unsure about starting a business and can be intimidated when dealing with licensing offices and financial institutions.

$\S$ Time availability: Women tend to have less time than men, given their family responsibilities.

Therefore it may be difficult for them to stand in line in financial institutions or free up time to effectively start their own business.

$\S$ Mobility: Women often have limited mobility (stemming from domestic responsibilities, cultural factors or even the lack of access to transportation). This constrains their ability to carryout business in numerous ways including attending training, and searching out new markets and possible suppliers.

$\S$ Access to labour: Although women may draw on the labour of daughters and other female family members, they often have difficulty drawing on male family labour (or contracting male wage laborers). Therefore their access to labour as an input may be more restricted than men's.

$\S$ Differences among women: Women's interests vary (economic position, age, and education levels, for example) and it cannot be assumed that all women can participate and benefit to the same degree. Although these trends have been documented across continents, lessons indicate that each situation is different. Therefore the meaningful participation of potential beneficiaries is important in both the design and implementation of initiatives. www.sida.se

\subsection{Definition and History of Micro credit}

Micro credit is the extension of very small loans (micro loans) to the unemployed, to poor entrepreneurs and to others living in poverty who are not considered bankable. These individuals lack collateral, steady employment and a verifiable credit history and therefore cannot meet even the most minimal qualifications to gain access to traditional credit. Micro credit is a part of microfinance, which is the provision of a wider range of financial services to the very poor. (www.wkipedia.org). Micro credit is a financial innovation which originated in Bangladesh where it has successfully enabled extremely impoverished people to engage in self-employment projects that allow them to generate an income. In addition, it has enabled the poor to build wealth and exit poverty. (www.wkipedia.org)

\subsection{Experiences from other Countries: Grameen Bank of Bangladesh}

Muhammad Yunus, a professor of economics at Chitagong University started a similar experiment to the ACCION experiment although independently. Around 1974, during a famine in his native Bangladesh, Yunus discovered that very small loans could make a difference in a 
poor person's ability to survive, but that traditional banks were not interested in making tiny loans to poor people, who were considered repayment risks. His first loan consisted of $\$ 27$ from his own pocket which he lent to 42 people including a woman who made bamboo furniture, which she sold to support herself and her family.

In 1976, Yunus founded the Grameen Bank to make loans to poor Bangladeshis. Since then, the Grameen Bank has issued more than $\$ 5$ billion in loans to several million borrowers. At the close of 2005 the number of outstanding loans is more than 4 million. To ensure repayment, the bank uses a system of solidarity lending through "solidarity groups": small informal groups, nearly all of them exclusively female, that meet weekly in their villages to conduct business with representatives of the bank and that support each other's efforts at economic self-advancement. As it has grown, the Grameen Bank has also developed other systems of alternate credit which serve the poor: in addition to microcredit, it offers housing loans, financing for fisheries, irrigation projects, venture capital, textiles, and other activities, as well as other banking services such as savings.

The success of the Grameen model has inspired similar efforts throughout the developing world and even in industrialized nations including the United States. Many, but not all, microcredit projects also emulate its emphasis on lending specifically to women. Close to 96 percent of Grameen loans have gone to women, who have been found to be much more likely than men to repay loans and to devote their earnings to serving the needs of the entire family. Originally, the program started with men and women but later focused on women when data showed a dramatically lower credit risk in women. In 2006, Yunus and the Grameen bank were honored for this achievement with the Nobel Peace Prize.

\subsection{Women-focused Micro-Finance Initiatives: A Kenyan Experience}

Available evidence points, in one way or another, to the considerable potential of micro-finance for the empowerment of women:

- Women's demand for credit and savings facilities is high;

- Women's savings propensity and loan repayment rates equal or exceed those of men;

- Many women, particularly in programs targeting women entrepreneurs, decide on the use of the loan and invest in income-earning activities;

- Some women are able, over a cycle of several loans, to increase incomes that they themselves control.

However, MF targeted to women and financed by MFIs is often seen as part of a poverty reduction program rather than as an economic, business development tool. Women micro enterprisers tend to operate in an environment with low investment, low growth potential, endure harassment on issues pertaining to licensing, operate in safe, cheap and "possible to get" premises, if not home-based, and have fewer hours to invest in their businesses due to domestic responsibilities. These women tend to have little or no education and often lack confidence - all factors affecting growth. (Linda Mayoux, "Micro-finance and the Empowerment of Women: A Review of Key Issues", Social Finance Unit, International Labour Office, Geneva.).An additional factor is that it cannot be assumed that the woman entrepreneur has control, or even an 
Journal of Entrepreneurship and Project Management

ISSN 2520 - 9116 (Online)

Vol.2, Issue No.2, pp 17- 39, 2017

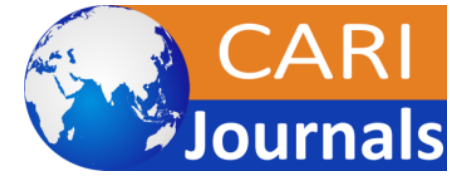

WwW.carijournals.org

effective say, over loan use, even is she secures the loan from a programme targeted specifically to women. Women may simply be used as low-cost and reliable intermediaries between loan program staff and male family members. Professional staff find it more convenient to deal with women because they are at home during working hours; male clients have neither the time nor the inclination to attend group meetings. In some reported cases, women do not even know that their husbands have taken a loan in their names. (Coetzee, Kabbucho, \& Minjama, 2002). Kenya has at least three micro-finance organizations specifically focused on women entrepreneurs - the Kenya Women Finance Trust (KWFT), Women Economic Empowerment Consort (WEEC), and the Women's Economic Development Corporation (WEDCO).

\subsubsection{The Kenya Women's Finance Trust}

The Kenya Women's Finance Trust started in 1981, the first African affiliate of the New Yorkbased Women's World Banking. Its goal was to help eradicate poverty in Kenya by making micro-credit available to low-income women operating in the informal and MSE sector. It has grown to become the largest provider of MF in the country, boasting an active client base of almost 75,000 women in 2003. Structured to "reach" women in both urban and rural areas, KWFT has invested in infrastructure and networks so they can serve women in towns and villages. It operates with a staff of 260, located in Nairobi, six regional offices and 32 unit offices, covering all regions except the desert north. To secure its micro-loan funds, KWFT borrows from partner banks (e.g., Barclays Bank of Kenya, the Kenya Commercial Bank, K-Rep Bank and Stanbic Bank), using client "savings", which are held in a Fixed Trust Account, to serve as loan collateral. These Trust Account savings provide 10 per cent of the loan security and were sufficient to convince banks to partner with them. They have also attracted funding from such donors as the Ford Foundation and USAID. (Coetzee, Kabbucho \& Minjama ,2002)

In 2003, KWFT disbursed over Ksh. 1.5 billion to member groups, showing 73,000 active members and 49,000 outstanding loans in their accounts; Ksh. 770 million was outstanding. The average loan size to members of groups is about Ksh. 20,000. To be eligible for a KWFT group programme, the group must be registered with the Ministry of Culture and Social Services as a self-help group, have existed as a group and operated a merry-go-round for at least one year, and must accept that they have to save an agreed amount of money on a monthly basis. The minimum savings is KShs. 200 per month. Members must agree to use the savings as collateral for group and individual member's loans. During the mobilization stage, groups complete eight weeks of training to build their capacity and enable them to fully utilize the credit they access. A recent innovation of KWFT is the introduction of loan insurance, which they are encouraging their clients to buy. They are also currently piloting an individual loan programme to meet the needs of growth-oriented clients with financing needs of KShs. 100,000 to KShs. 500,000 (Coetzee, Kabbucho, \& Minjama, 2002).

\subsection{RESEARCH METHODOLOGY}

A qualitative and quantitative case study was adopted. The target population was included all the Kabete women groups financed by the KWFT Kabete branch. The basic unit of KWFT organizational structure is a grass root group made up of 5 borrowers from the same villages that know one another. 10 such groups make up a center, an informal association of bank members at the 
village level and most of the bank's transactions take place at the center during regular weekly meetings. 20 centers make up a bank branch. Consequently, the number of groups was 200 with a total of 1000 members. As it not feasible for the researcher to study every member in the target population, a sample of $10 \%$ was considered representative (i.e. 20 groups). A nonrandom/non probabilistic sampling technique was used to select 3 respondents from the various groups where the Group leaders such as Chair lady, Treasurer and Secretary were requested to fill in the questionnaires which were the instruments for data collection. The data collected was analyzed by use of descriptive and inferential statistics. In particular, frequency tables and proportions or percentages were used. The data was then presented using charts and graphs.

\subsection{RESULTS AND DISCUSSIONS}

\subsection{Institutional and Gender Impediments to Women Owned SMEs}

According to this study, inadequate market and promotion was cited as a primary cause of women SME failure and this was supported by the majority response (agreed, 65\%). Poor provision of land workspace and land infrastructure facilities was a primary cause of women SME failure as shown by the majority $(60 \%)$ of responses who agreed. These findings are consistent with those of McCormick (1992). Gichira(1992) and Armin Sethna(1992) which alluded that the majority of SMEs competed for a limited market and rarely used advertising in the print and other media as it was costly to do so.

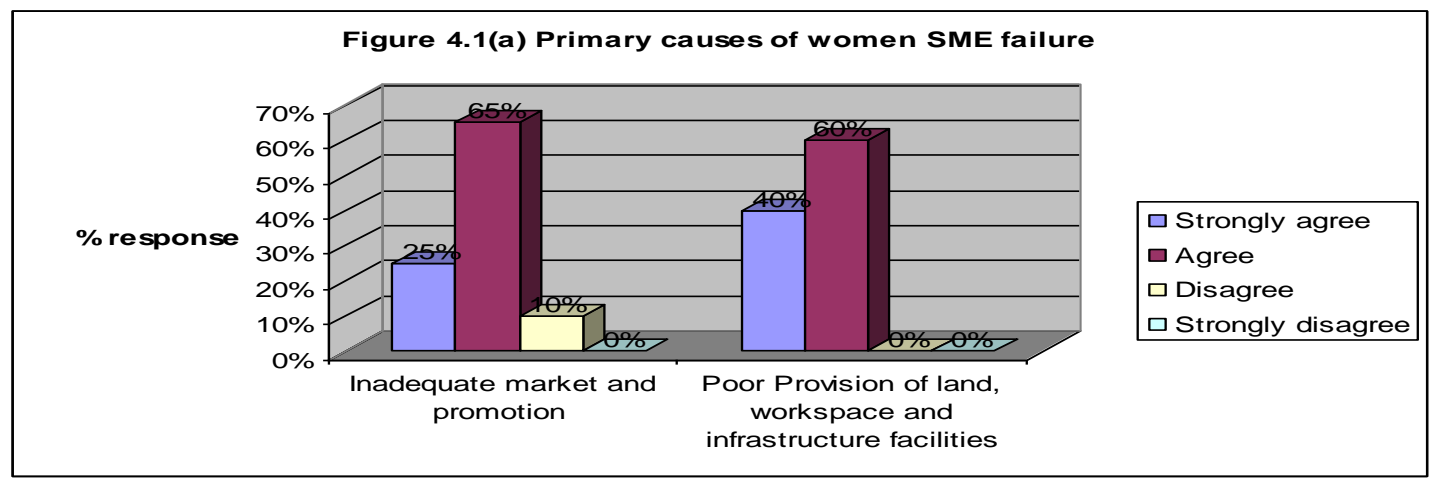

\section{Figure 1: Primary Causes of Women SME Failure}

The majority ( $70 \%$ and $52 \%$ ) of the respondents strongly agreed that inadequate access to finance and stringent legal and licensing procedures were primary causes of women SME failure respectively. 


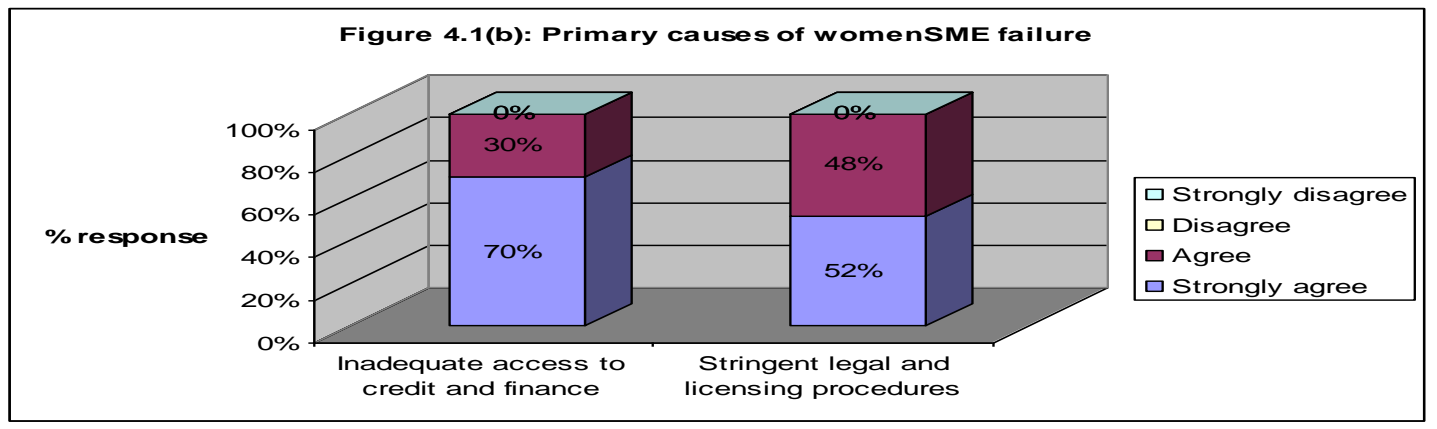

\section{Figure 2: Primary causes of women SME Failure}

In addition, $30 \%$ and $48 \%$ of respondents agreed respectively. These findings are consistent with findings by Harper (1976) who alluded that SME owners had more business ideas than they have the money to put them into effect. Studies by Dondo (1990) also alluded that micro finance institutions availed very small loans which were nor suitable for some businesses. Hence there was need for more specialized institutional and financial support. The Studies by Harper (1976) states that a tightly regulated economy work against small enterprises since large firms have capacity and resources to get around regulations or bend the rules in their favor but small enterprises are caught in them and this affect their growth.

The majority (65\%) of the respondents agreed that inappropriate information and technology was a primary cause of failure in women SMEs. While $35 \%$ of respondents strongly agreed with this statement, no other response was observed. This finding is consistent with studies by Hodgetts and Kuratico (1989) which noted that most small enterprises lack access to vital business information and therefore fail to take advantage of services provided by government or other organizations. In addition, these findings agree with those of Sethna (1992) who observed that small enterprises use simple technology that is often human powered and this limits the quantity of goods to be produced and hence the growth of the enterprise. Competition was identified as a primary cause of business failure and this finding were supported by the majority of respondents who strongly agreed with the statement. While $26 \%$ of the respondents agreed with this statement no other response was observed. It is the researcher's opinion, that heavy competition arose from limited markets and most entrepreneurs produced the same types of products.

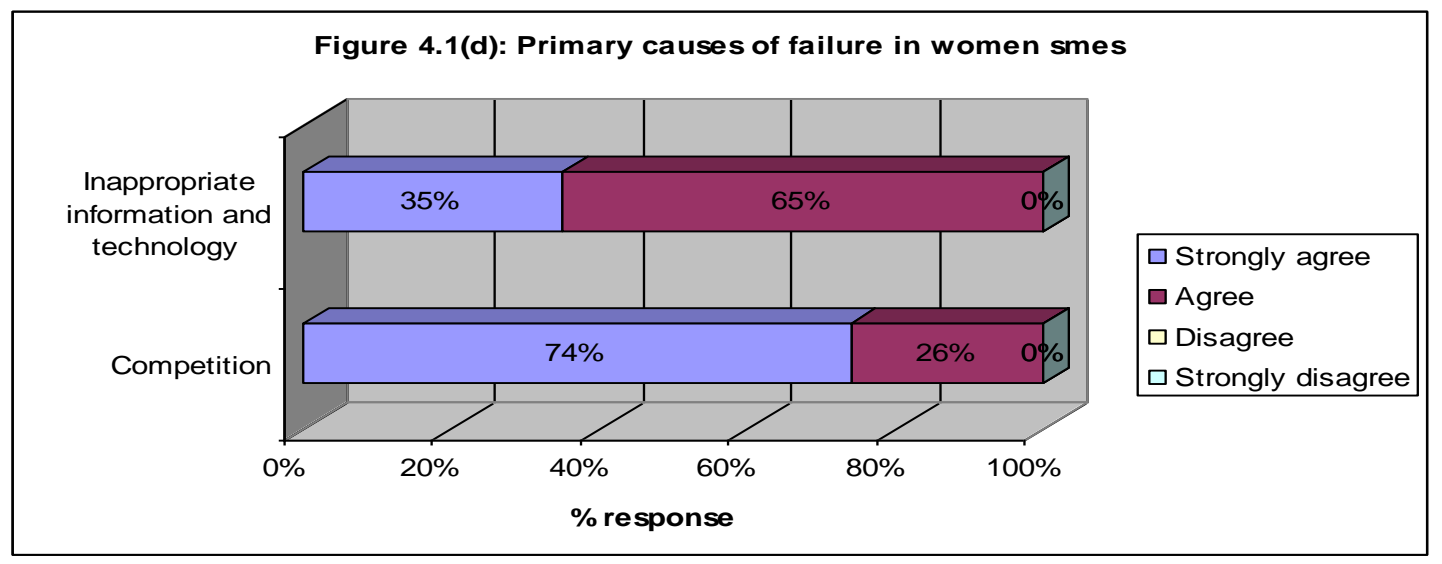




\section{Figure 3: Primary Causes of Women SME Failure}

According to this study, lack of technical management training was cited by as a primary cause of women SME failure. This finding was supported by the majority (82\%) who strongly agreed. A further $18 \%$ agreed with the statement. These findings are consistent of those brought about by National baseline survey (1999) which revealed that $85 \%$ of entrepreneurs had not received technical and management training. Inadequate entrepreneurship and business development services (BDS) such as insurance and project appraisal were quoted as primary cause of women SME failure. This finding was supported by a majority of respondents (54\%) who strongly agreed. Meanwhile, $46 \%$ agreed with the statement. These findings are similar to the National baseline survey (CBS/ICEG/KREP 1999) which indicated that only $7 \%$ had received business development services.

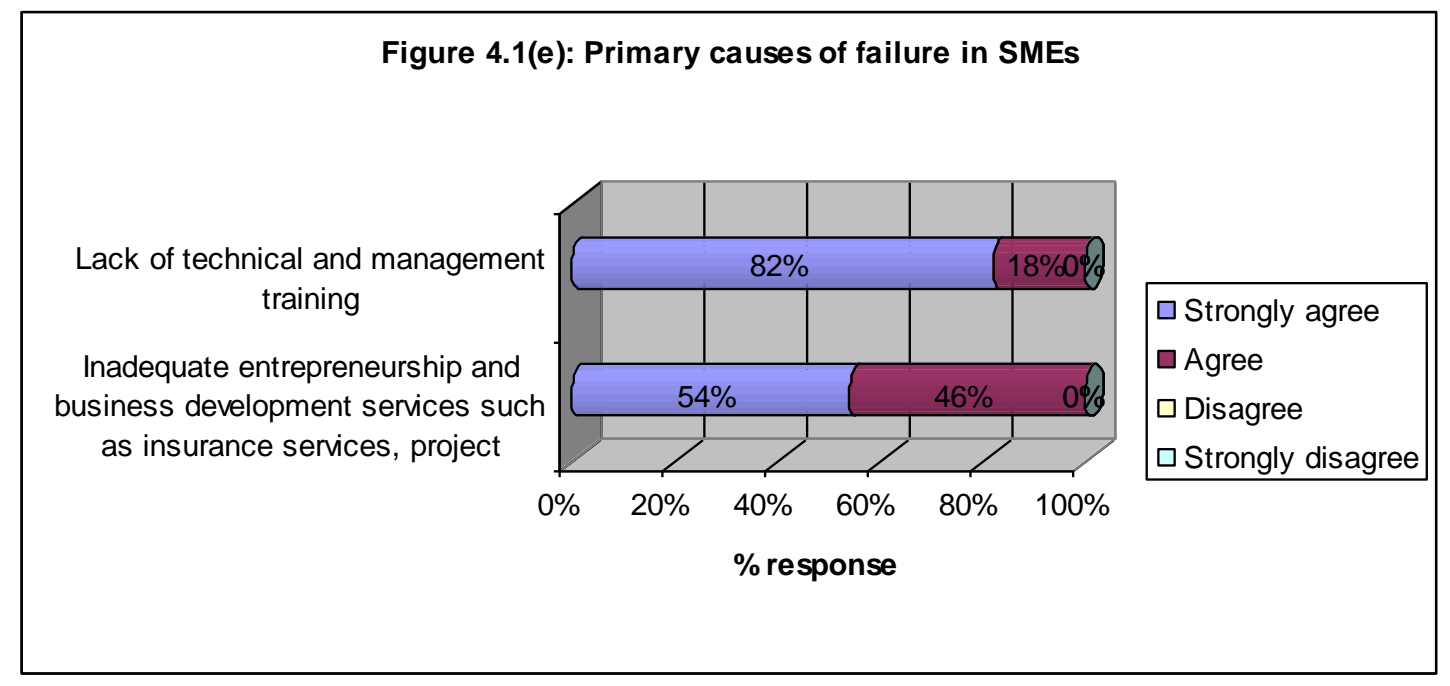

\section{Figure 4: Primary Causes of Women SME Failure}

Gender issues were also recognized as important determinants to the success or otherwise of women SMEs. To a large extent, it was identified that poor women had less education than poor men and this contributed to women SME failure. This finding was supported by majority $(72 \%)$.The gender issue of women having unequal access to productive resources e.g. collateral such as title deeds was to large extent a factor contributing to women SME failure. This finding was supported by $70 \%$ of the respondents. These findings are also consistent with literature review. Meanwhile, $18 \%$ and $20 \%$ respectively indicated that the two gender issues were to moderate extent contributors to women business failure. However, $10 \%$ in both cases indicated contribution to a low extent by both gender issues. 


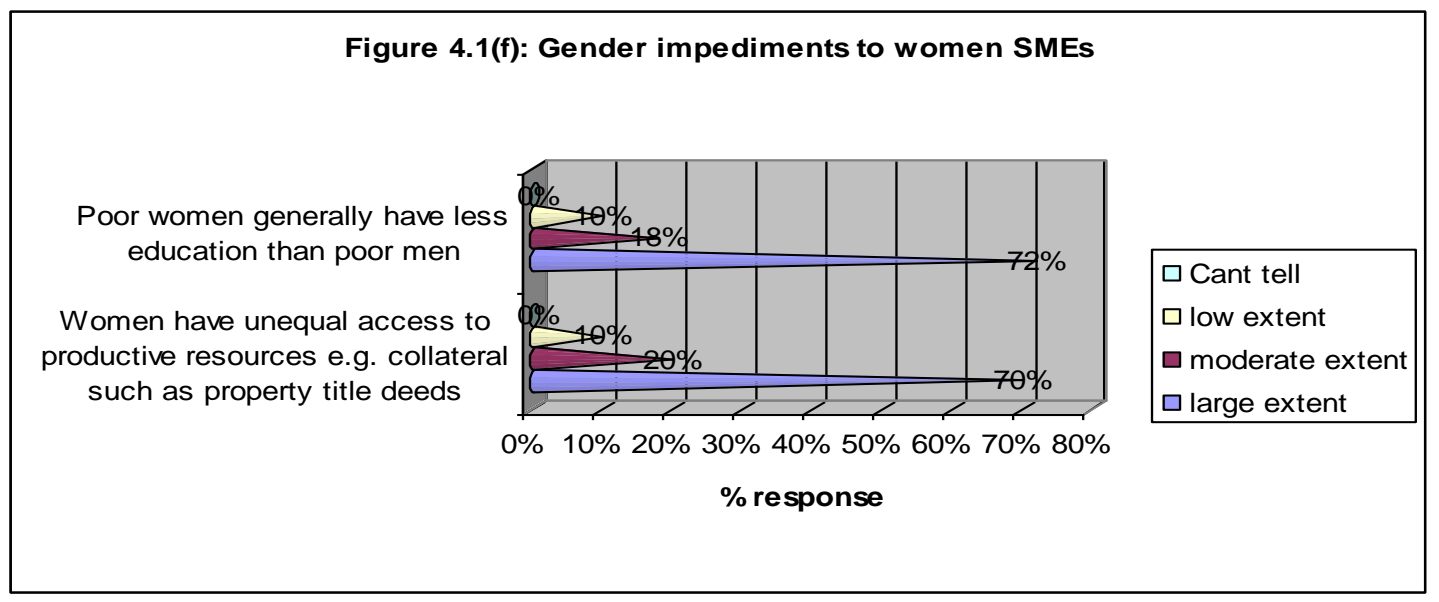

\section{Figure 5: Gender Impediments to Women SMEs}

To large extent (80\%), women have less self-confidence to start and manage a business hence its failure. To a moderate extent $(8 \%)$ women are have less self-confidence to start a business. Meanwhile, $12 \%$ could not make up their mind on the extent to which women had selfconfidence to start a business. According to literature review, women lack of self confidence in starting and managing a business was a gender issue determining the success or other wise of women SMEs.

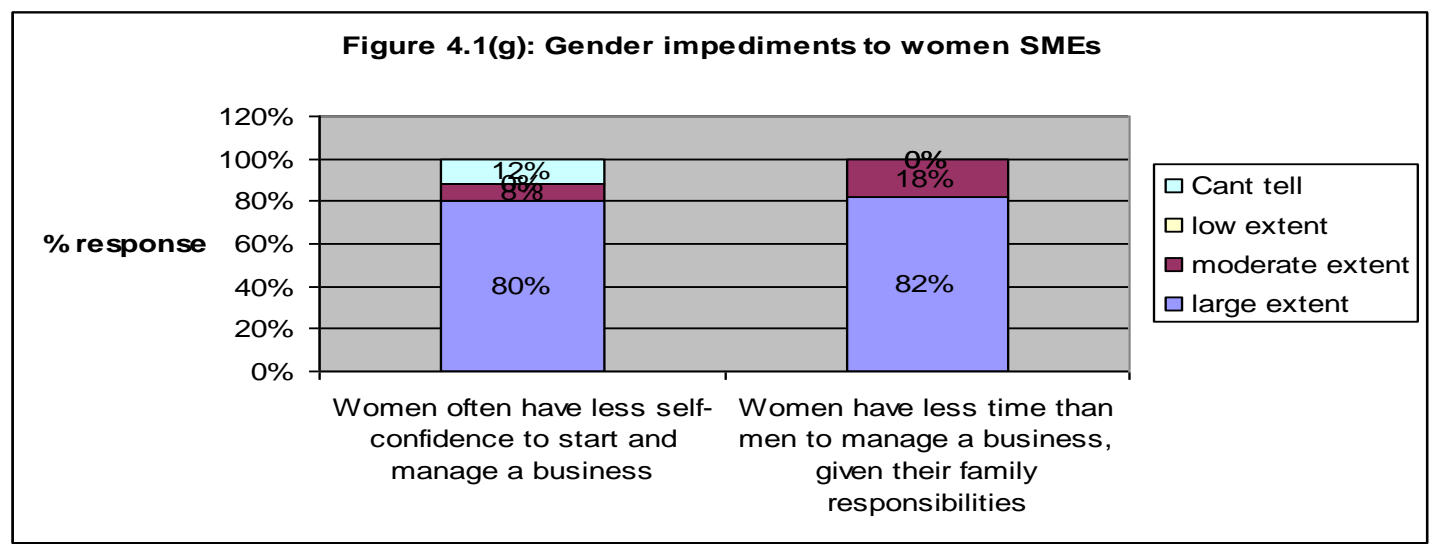

\section{Figure 6: Gender Impediments to Women SMEs}

It was also identified that women had less time than men to manage a business given their family responsibilities. Therefore, this to a large extent (82\%) contributed to women SME failure. Meanwhile, $18 \%$ of respondent indicted that this gender issue contribution was to a moderate extent. Findings in this study indicate that gender issues such as women interests varying more than men, access to male labor being more limited for women than men and women low mobility due to domestic responsibilities were to a large extent gender contributors to women SME failure. This was evidenced by a majority response of $56 \%, 75 \%$ and $65 \%$ respectively. 


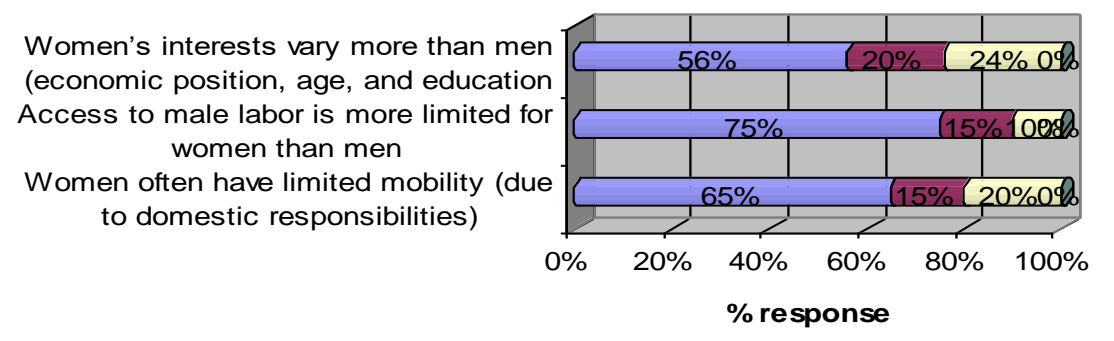

\section{Figure 7: Gender Impediments to Women SMEs}

Meanwhile, contribution of these gender issues to women SME failure was to a moderate extent $20 \%, 15 \%$ and $15 \%$ respectively. However, 24\%, $10 \%$ and $20 \%$ indicated to a low extent.

\subsection{Capacity Building and Training Needs for Women}

According to literature review, one of the biggest challenges to women development as well as the development of their projects was inadequate training. Findings in this study indicate that the majority (64\%) of women had to a low degree received formal training in entrepreneurship such as business growth management skills. While, $10 \%$ indicated that they had received formal training to a high degree, a further $26 \%$ indicted that they had not receiving any formal training at all. The majority of women (74\%) had also received formal training in marketing and presentations skills to a low degree. It was also noted that $8 \%$ of women had received this formal training to a moderate degree. However, it was also noted that $18 \%$ of women had not undergone any formal training in this field at all.

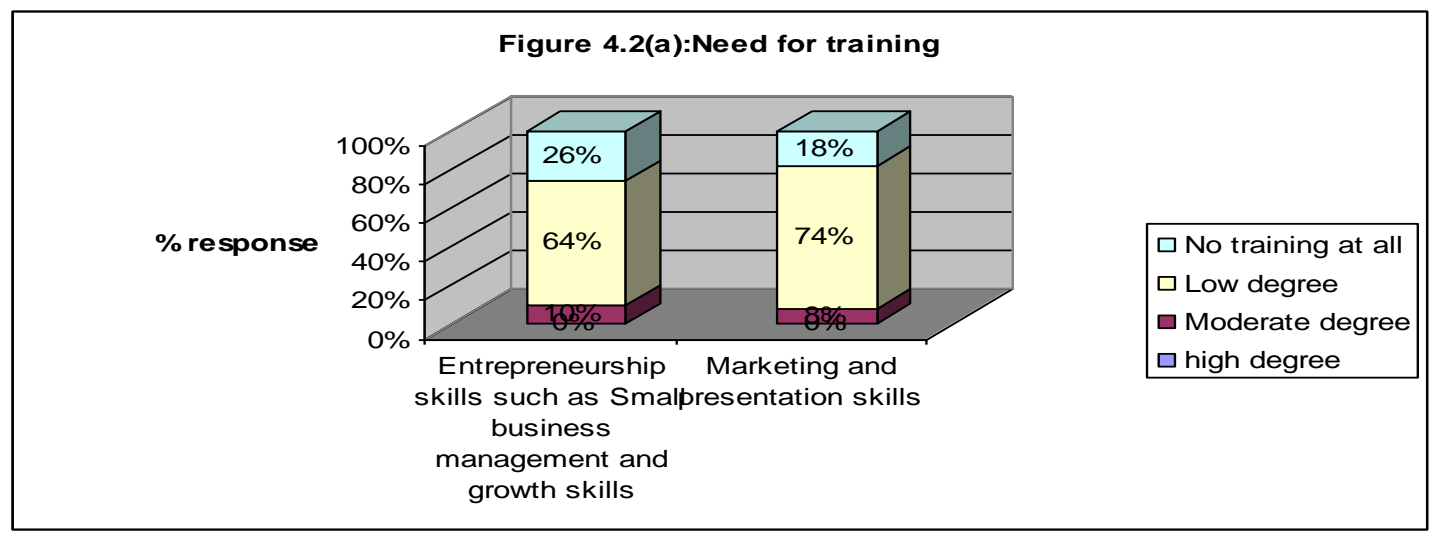

\section{Figure 8: Need for Training}

According to this study, the majority of women $75 \%$ had received no formal training in the field of risk management such as insurance and diversification. In addition, the majority (60\%) of women had to a moderate extent received formal training in computer skills to a low extent 
degree. It was also in this study that the majority (50\%) of women were found to have received no formal training at all in the field of cash flow and credit management.

It is the researcher's opinion, that the lack of formal training in cash and credit management may have been a significant contributor to the inability of women to make loan repayment on time.

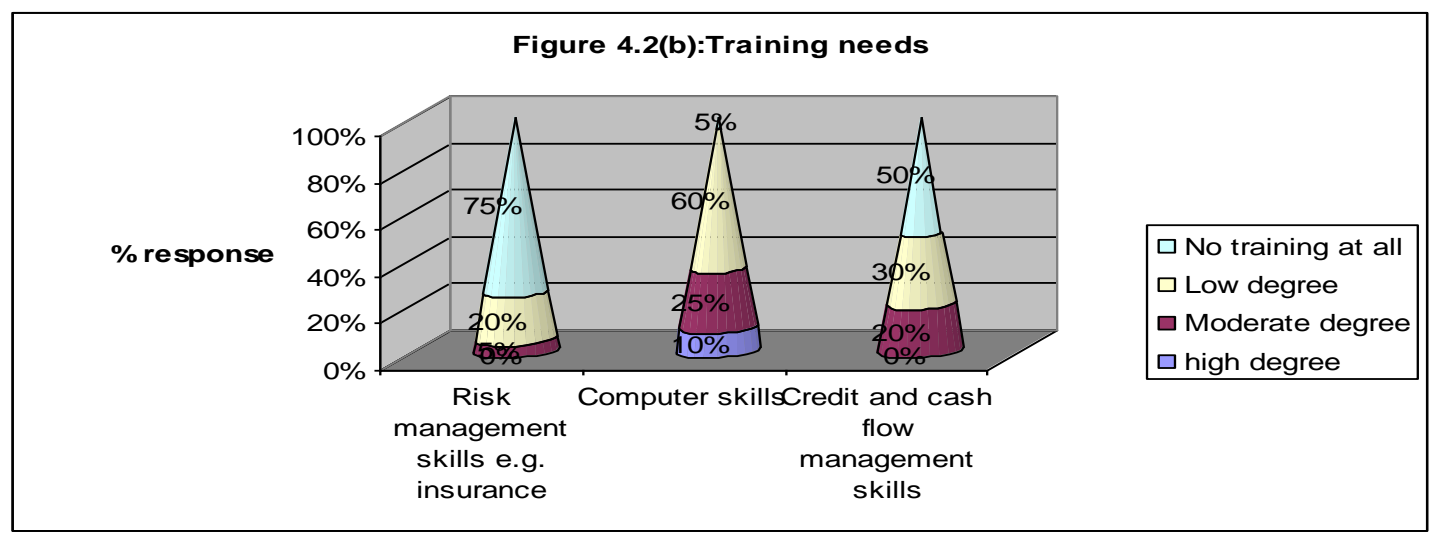

\section{Figure 9: Training Needs}

Findings in this study indicate that the majority of women (70\%) had received no formal training in accounting and book keeping. A further $20 \%$ of women had received accounting and book keeping training to a low degree. However, $10 \%$ of women had also received this training to a high degree. It was also in this study that $68 \%$ of women had not received any formal training in commercial law skills such as SME regulation and licensing as well as the law of contract.

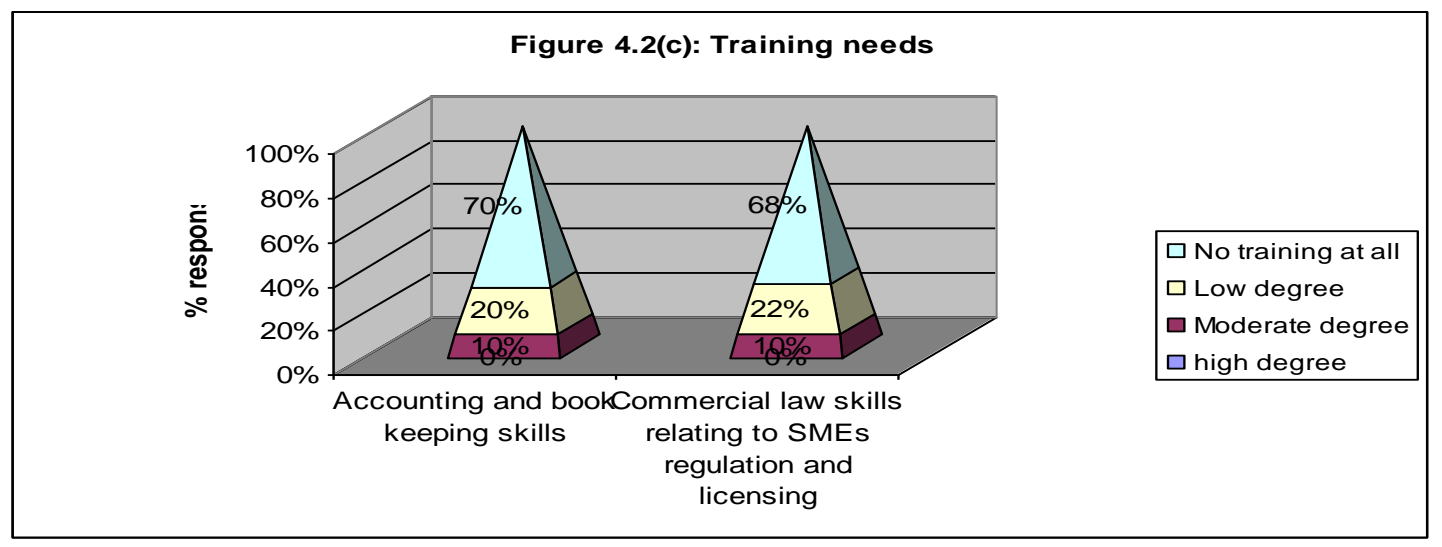

\section{Figure 10: Training Needs}

However, it was also identified that while $22 \%$ had received this training to a low extent, a further $10 \%$ had received formal commercial law training to a moderate extent.

\subsection{Challenges in Repayment of Loans}

The majority of respondents $(70 \%)$ indicated that they found borrowing and repayment terms of the microfinance in which they were members to be moderately flexible. In addition, $20 \%$ of members found the borrowing and repayment terms to be very flexible and friendly. However, $10 \%$ of respondents found the borrowing and repayment terms of the micro finance to be very 
rigid and unfriendly. It is the researcher's speculation that those who found the borrowing and repayment terms unfriendly and rigid may have been victims of penalties after failing to repay loans on time.

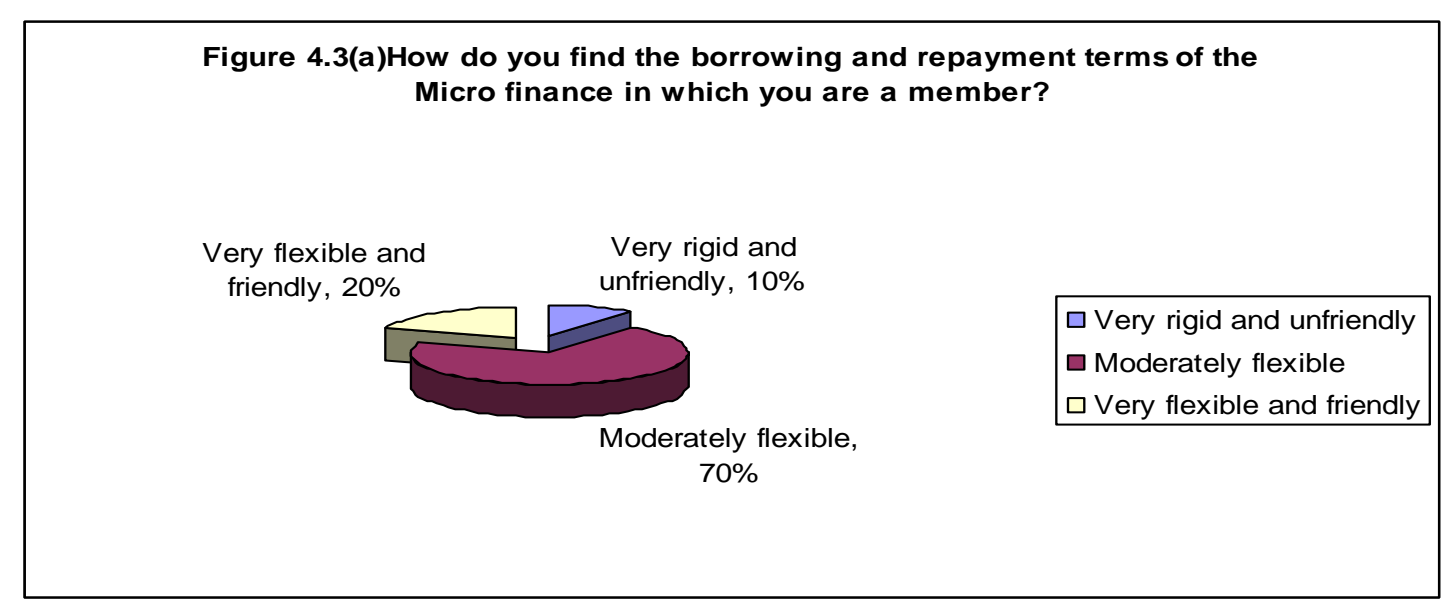

\section{Figure 11: Challenges in Repayment of Loans}

Findings in this study indicated that the majority of respondents $(70 \%)$ had been in a cash flow constraint which affected their ability to repay their loans promptly. While $30 \%$ said that they had never been in such a cash flow constraint no further response was obtained for this question. Nonetheless, it is the researcher's opinion that the accuracy of this findings may be limited to the extent of respondents honesty as it is a widely established notion that people don't like exposing their weaknesses due to fear of retribution.

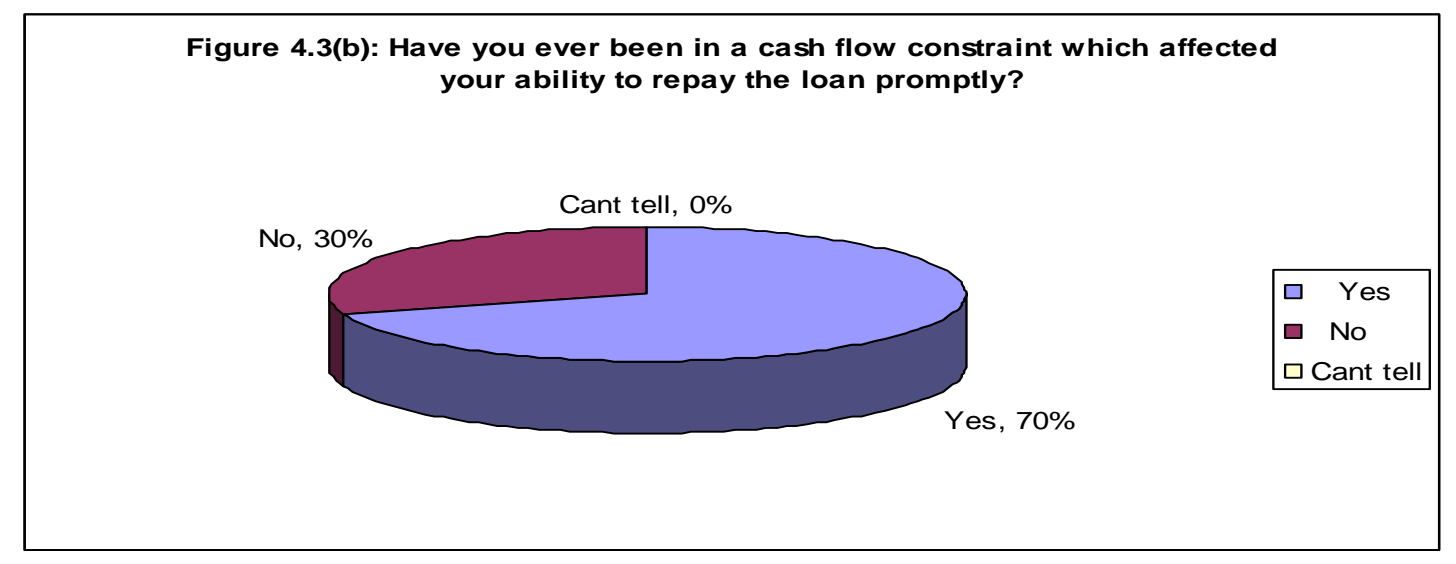

\section{Figure 12: Challenges in Repayment of Loans}

While attempting to determine the frequency with which defaults or delays in repayment of loans occurred, the researcher found out that the majority of respondents $(55 \%)$ had experienced loan repayment problems more than two times since the time they were advanced with a loan. It was also identified that $10 \%$ indicated that they had delayed payment twice, $5 \%$ indicted once while $30 \%$ indicated that they had never delayed on loan repayments. 


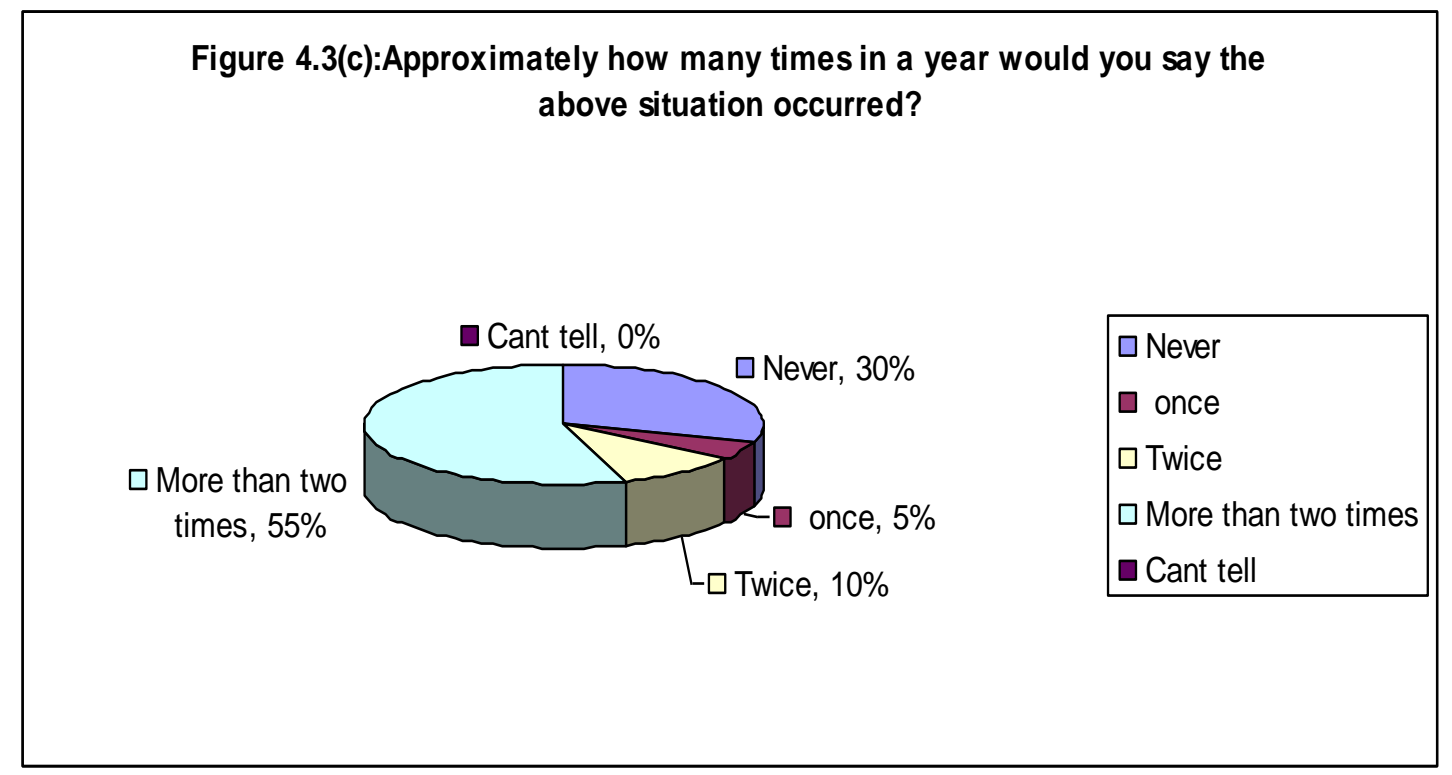

\section{Figure 13: Challenges in Repayment of Loans}

Again, the researcher wishes to point out that the accuracy of the above findings may be limited to the extent by which respondents answered honestly to this sensitive question.

In response to the question of how they would rate the growth and success of their business since they received a loan facility, a majority of respondents $(60 \%)$, indicated that they had not noticed any significant growth in their business. In addition, 10\% indicted that their business had actually contracted to the extent of failure.

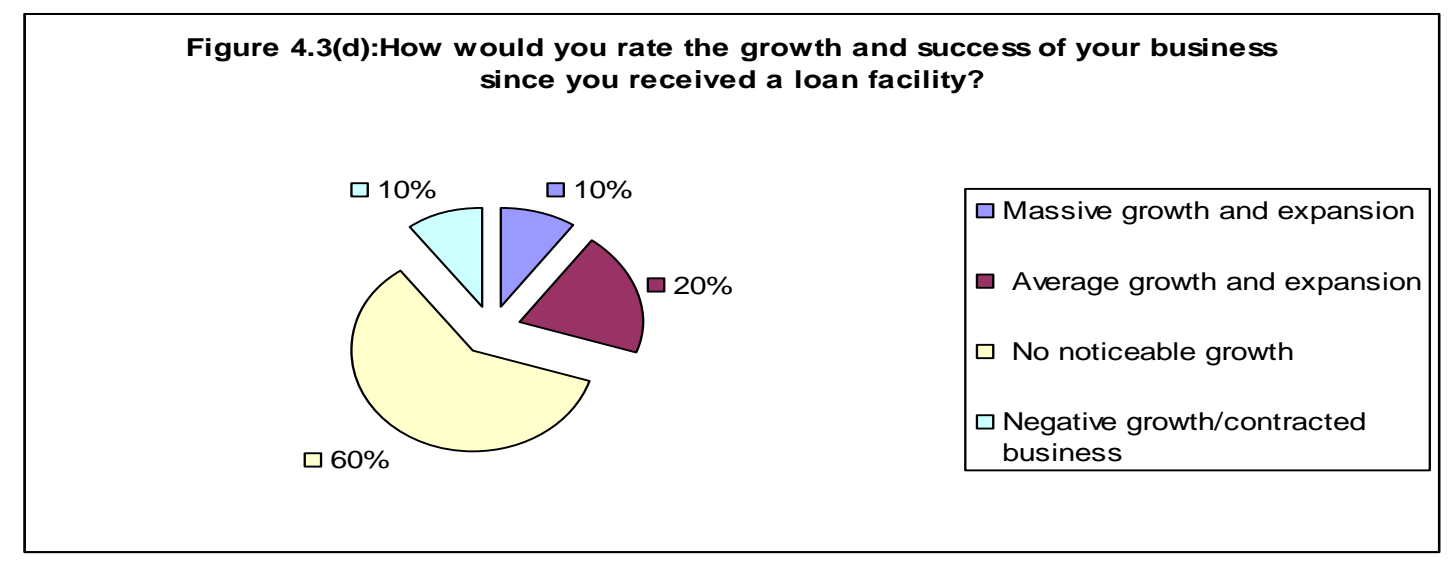

\section{Figure 14: Challenges in Repayment of Loans}

However, it was also noticed that $20 \%$ of the business had undergone average growth and expansion while another $10 \%$ had seen massive growth and expansion from the moment the owner received a loan facility. 


\subsection{Effect of Micro Credit on Living Condition of Borrowers}

According to this study, the majority of women borrowers (54\%) disagreed that access to micro credit had greatly improved their ability to provide a better balanced diet for their families. In addition, $9 \%$ strongly disagreed with this statement. While $15 \%$ of the women borrowers agreed with this statement a further $12 \%$ strongly agreed. These findings are consistent with other studies such as Mayoux (2000) and Kabeer (1998) underscored in literature review.

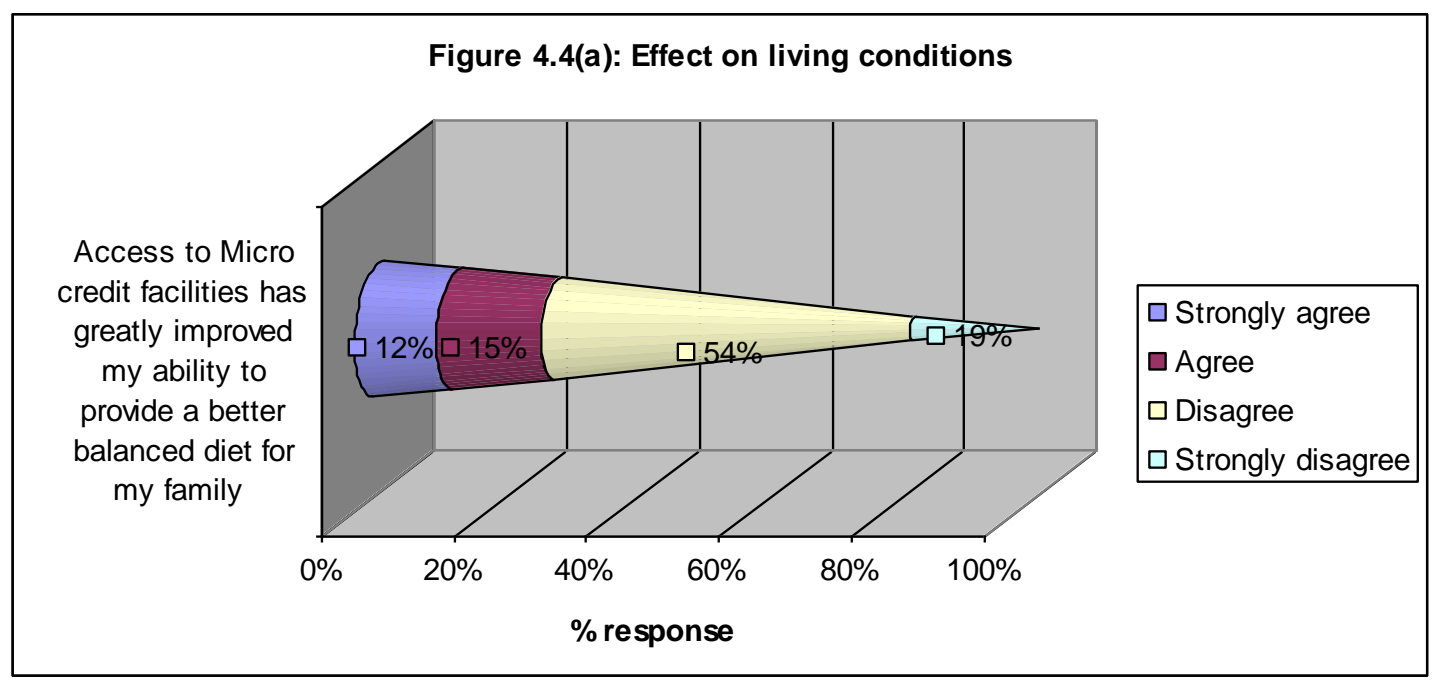

\section{Figure 15: Effect of Micro Credit on Living Condition of Borrowers}

In this study, the majority of women borrowers (60\%), disagreed with the statement that access to micro credit had greatly improved their ability to provide for health needs for their family. In addition, $15 \%$ strongly disagreed with this statement. While $10 \%$ of women borrowers agreed with this statement, a further $15 \%$ strongly disagreed with the statement.

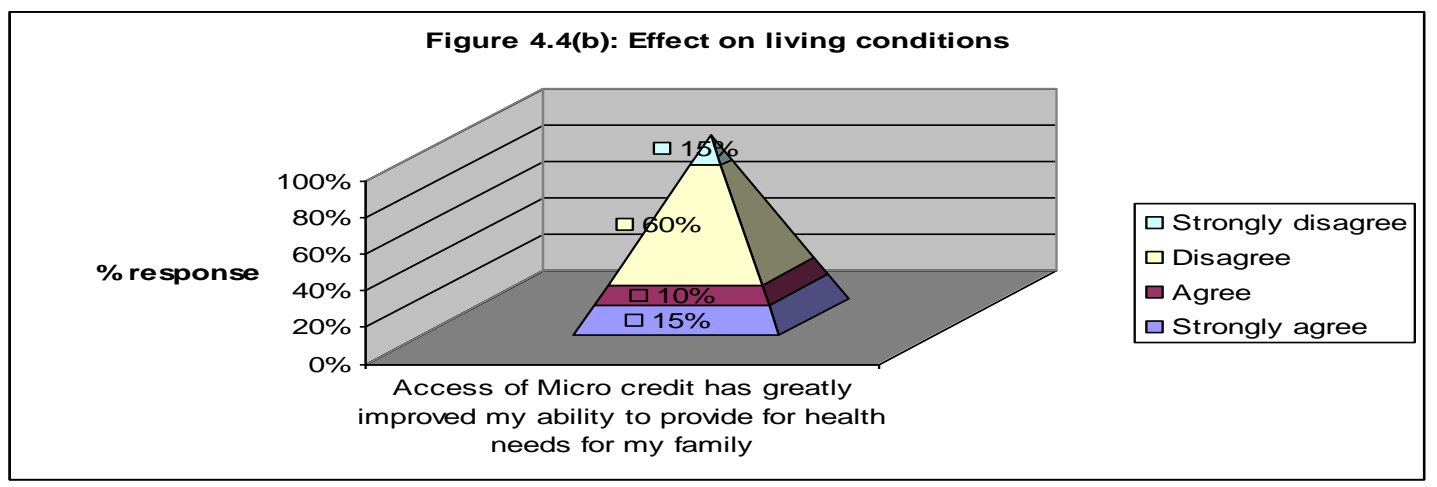

\section{Figure 16: Effect of Micro Credit on Living Condition of Borrowers}

It was in this study that the majority of women borrowers $(65 \%)$ disagreed with the statement that access to micro credit had greatly improved their ability to provide better educational facilities for their family. It was also noted that another $15 \%$ strongly disagreed with this statement. However, $10 \%$ and $10 \%$ agreed and strongly agreed with this statement respectively. 


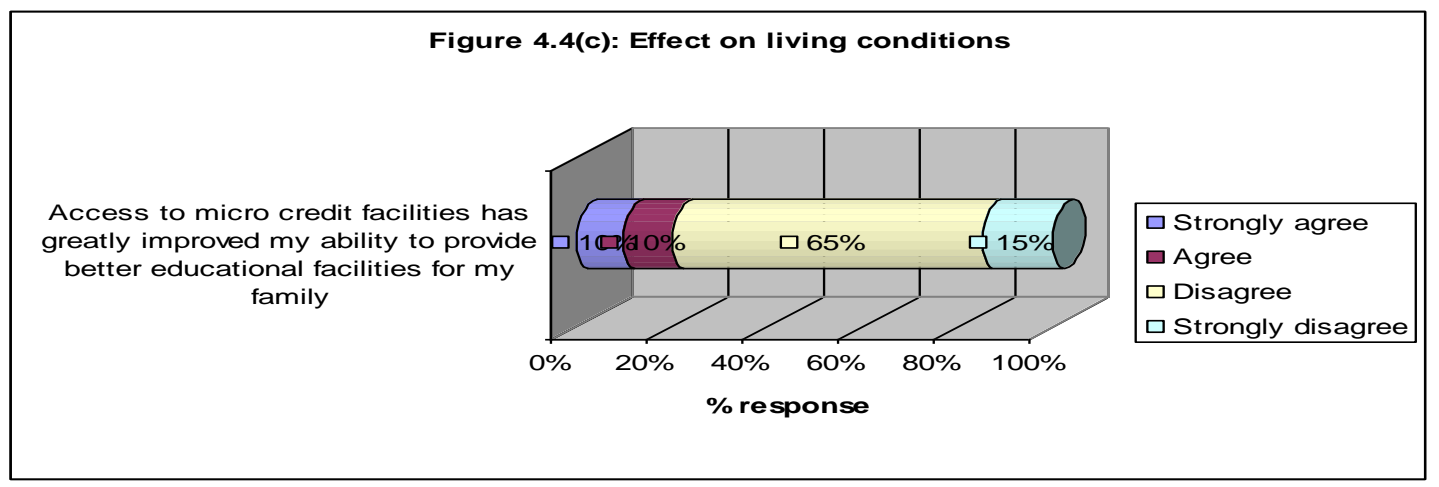

Figure 17: Effect of Micro Credit on Living Condition of Borrowers

Findings in this study indicated that the majority of women borrowers disagreed with the statement that access to micro credit facilities had enabled them to get cash for saving and other uses. In addition, $10 \%$ strongly disagreed with this statement. Nonetheless, $15 \%$ agreed while a further $5 \%$ strongly agreed with this statement.

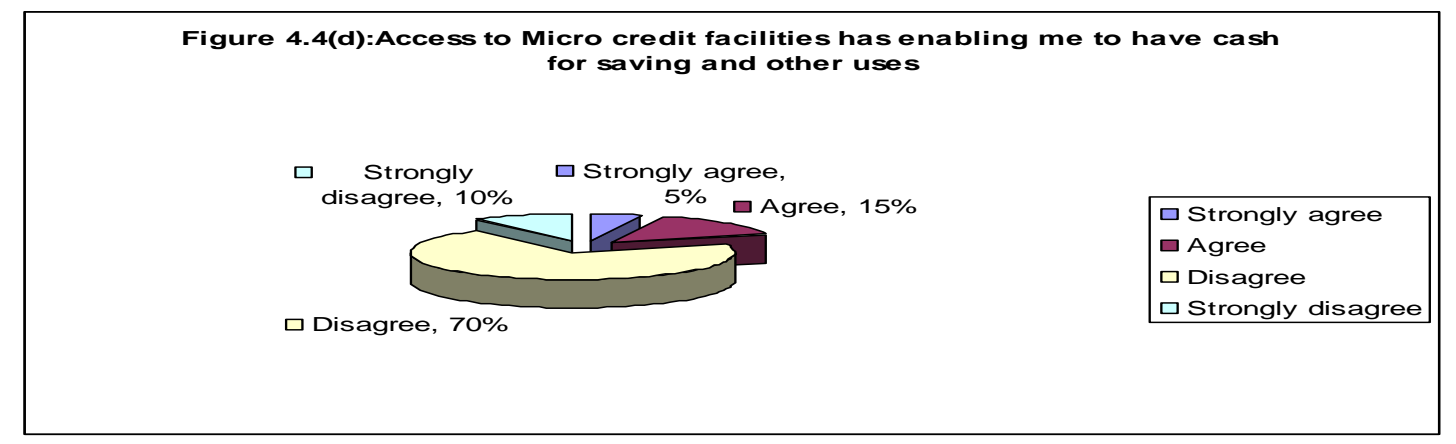

Figure 18: Effect of Micro Credit on Living Condition of Borrowers

\subsection{DISCUSSION CONCLUSIONS AND RECOMMENDATIONS}

\subsection{Findings}

According to the first objective, several factors were identified to be primal to women SME failure. The majority of respondents strongly agreed that inadequate access to finance, stringent legal and licensing procedures, competition, lack of technical and managerial training as well as inadequate entrepreneurship and business development services were primary causes of women SME failure. It was also identified that the majority of respondents agreed that poor provision of work space, land and other infrastructure as well as the inappropriate use of information and technology were primary causes of women SME failure.

Gender issues also caused women SME failure. To a large extent, gender issues such as poor women having less education than poor men, women having unequal access to productive resources, women having less confidence to start and manage a business, women having less time than men to manage their business given their family responsibilities, variation in women 
interests and the limited mobility of women owing to their domestic responsibilities caused women's SME failure.

In line with the second objective various training needs were identified for women participating in SMEs. It was noted that majority of women borrowers had received no formal training in risk management, credit and cash flow management, accounting and bookkeeping, commercial law such as licensing procedures and the law of contract. Furthermore, women borrowers had to a low degree received formal training in entrepreneurship skills such as business growth management, marketing and presentation and computer skills.

In relation to the third objective, the majority of women borrowers had a challenge in prompt repayment of loans advanced by micro credits. This was observed despite the majority still claiming that the borrowing and repayment terms were moderately flexible. It was also identified that the majority of borrowers had experienced cash flow constraints forcing them to delay repayment more than two times since the commencement of the loan facility. Moreover, the majority of women borrowers claimed that they had not noticed any growth in their business after taking on a loan facility. Incidentally, some even claimed that their business had indeed contracted to the extent of collapse.

Finally, it was also important to find out whether the availability of micro credit facilities had a positive effect on the living condition of the women borrowers and their families. Findings in this study indicated that the majority of women borrowers did not see an improvement in the ability to offer a balanced diet, health facilities, better education facilities and increase in cash for saving as well as for other uses.

\subsection{Conclusions}

With support from findings as well as literature review, the researcher concludes that the main causes of failure of women projects funded by MFIs can be attributed to the general SME constraints such as competition, lack of technical training and capacity building and inappropriate information and technology. In addition to factors delineated in the summary of findings, genders issues such as women immobility, lack of confidence, inadequate time and unequal distribution of productive resources have also been responsible for the decline and failure of women SMEs funded by local MFIs. It was also in order to infer form the findings that low degree of formal training in various business areas was a state common with many women undertaking projects funded by local MFIs.

Finally, the researcher was able to conclude that despite local MFIs offering flexible borrowing and repayment terms, majority of women borrowers found it difficult to repay loans on time. It was also in this study that the researcher was able to infer and agree with literature review that majority of women projects had not expanded nor contracted i.e. no noticeable growth. Nonetheless, it was unfortunate that a significant portion of women projects had actually collapsed as a result of the general and gender constraints listed in this study. Due to this status quo, the researcher finally concluded that the provision of micro credit did not necessary lead to an improvement in the living condition of the women borrowers and their families. 


\subsection{Recommendations}

Several recommendations were floated to the issues raised above. It was noted that for the success of women projects funded by local MFIs to be a reality, general constraints to SMEs and gender disparities needed to be sorted out.

The policy calling for improvement in the legal and regulatory framework require a comprehensive review of all pertinent Acts in order to determine the extent to which such acts have adverse impact on SMEs. In line with this policy a unit should be set up to identify various laws and regulations hindering the growth of SMEs. Various task forces should be set up i.e. to review city council by - laws, land reform and rationalization of trade license among others. The policies outlined in Sessional paper No.2 of 1992 and all sessional papers following thereafter should implemented. These policies included review of lending regulations and procedures by central bank with a view to making collateral requirement more flexible, establish venture capital institution to provide SMEs with equity capital and establish SMEs departments in the major banks among other measures.

The government effort to create markets such as Muthurwa and the other potential markets should be reinforced by the provision of amenities such as water, sanitation and electricity in those markets. Furthermore, more work places and land need to be set aside for the construction of effective trading structures. The government and stakeholders as well need to come together and establish public private partnerships with the mandate of providing business training as well building capacity among SME owners.

\subsection{Suggested Areas of Further Research}

The researcher recommends a study on an analytical study shedding light to the reasons for the slow implementation of various policies aimed at benefiting the SME sector i.e. despite the government recognition of MSE sector as a very important job creating front. In addition, the researcher recommends an analysis of how other countries such as Bangladesh and India have successfully incorporated SMEs in their agenda of achieving the Millennium Development Goals (MDGs).

\section{REFERENCES}

Abedin, N. (1996). Grameen approach to development in Bangladesh: An overview. Contemporary South Asia, 5(2), 207-213.

Stevenson, L., \& St-Onge, A. (2005). Support for growth-oriented, women entrepreneurs in Kenya. International Labour Organization.

Bheemaraya, M. (2016). Micro finance developmental strategies to reducing poverty nuxes: An overview. International Journal of Research-Granthaalayah, 4(5), 7-18.

D’espallier, B., Guérin, I., \& Mersland, R. (2011). Women and repayment in microfinance: A global analysis. World Development, 39(5), 758-772. 
Ackerly, B. A. (1995). Testing the tools of development: credit programmes, loan involvement, and women's empowerment. IDS bulletin, 26(3), 56-68.

Ardener, S., \& Burman, S. (eds.) (1995). Money-go-rounds: The importance of rotating savings and credit associations for women, London: Berg Publishers (Includes case studies from around the world)

Chowdhury, M., Hossain, S., Kashem, M. A., Miah, M., \& Momen, A. (1998). Loan utilization behaviour of the women beneficiaries of Grameen Bank: An empirical study in Bangladesh. Economic Affairs (Calcutta), 43(3), 160.

Goetz, A. M., \& Gupta, R. S. (1996). Who takes the credit? Gender, power, and control over loan use in rural credit programs in Bangladesh. World development, 24(1), 45-63.

Hashemi, S. M., Schuler, S. R., \& Riley, A. P. (1996). Rural credit programs and women's empowerment in Bangladesh. World development, 24(4), 635-653.

Johnson, S., \& Kidder, T. (1999). Globalization and gender-dilemmas for microfinance organizations. Small Enterprise Development, 10(3), 4-15.

Kabeer, N. (1998). 'Money can't buy me love'? Re-evaluating gender, credit and empowerment in rural Bangladesh. Discussion Paper-Institute of Development Studies, University of Sussex (United Kingdom).

Khan, M. R. (1999). Microfinance, wage employment and housework: A gender analysis. Development in practice, 9(4), 424-436.

Khandker, S. R. (1998). Fighting poverty with microcredit: Experience in Bangladesh. NewYork: Oxford University Press for the World Bank

Koopman, J. (1996). Client Impact Assessment of Women's Entrepreneurship Development Program in Bangladesh. Prepared for USAID/Dhaka. Microserve Project. Washington, DC: Chemonics International.

Larance, L. Y. (1998). Building social capital from the center: A village level investigation of Bangladesh’s Grameen Bank. Center for Social Development Working Paper, (98-4).

Mayoux, L. (1999). Questioning virtuous spirals: micro-finance and women's empowerment in Africa. Journal of international development, 11(7), 957.

Mayoux, L. (2000). Micro-finance and the Empowerment of Women: A Review of the Key Issues (No. 344134). International Labour Organization. 